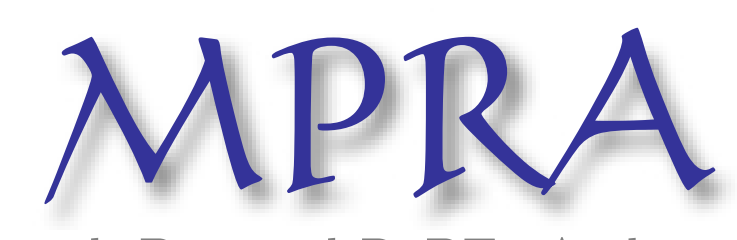

Munich Personal RePEc Archive

\title{
TECHNOLOGICAL INNOVATION ACTIVITIES IN FIRMS AND PROPENSITY OF INDIVIDUALS STARTING NEW BUSINESSES
}

Wong, Poh Kam and Lee, Lena and Foo, Maw Der

April 2007

Online at https://mpra.ub.uni-muenchen.de/2617/

MPRA Paper No. 2617, posted 08 Apr 2007 UTC 


\title{
TECHNOLOGICAL INNOVATION ACTIVITIES IN FIRMS AND PROPENSITY OF INDIVIDUALS STARTING NEW BUSINESSES
}

\author{
Poh-Kam Wong* \\ Lena Lee \\ NUS Entrepreneurship Centre
}

\begin{abstract}
Maw-Der Foo
National University of Singapore \& University of Colorado, Boulder

* Telephone: 65-65166323
\end{abstract}

Fax: 65-67732269

Email: bizwpk@nus.edu.sg 


\begin{abstract}
Prior studies have found that knowledge gained from work experience is a way to gather insights for business opportunity recognition. However, little is known about the specific types of knowledge that lead to business founding. Utilizing concepts from knowledge spillovers and from the opportunity recognition literatures, this paper argues that through an organization's technological innovation activities, employees develop specialized knowledge that provides them with the entrepreneurial opportunities to found new businesses. Besides highlighting the positive relationship between technological innovation activities in organizations and the propensity of individuals leaving the organizations to start new businesses, this paper also provides a more fine-grained explanation of the types of technological innovation activities that can lead to business founding. We argue that knowledge acquired through product innovations is more easily appropriated by individuals for commercial uses, while knowledge acquired through process innovations must be integrated with other parts of the organization to be valuable. This study proposes that product innovation activities in an organization more so than process innovation activities in an organization are related to new business founding. Implications for opportunity exploitation and ways to appropriate knowledge spillovers are discussed.
\end{abstract}

JEL Classification: M13, O31, C12 


\section{TECHNOLOGICAL INNOVATION ACTIVITIES IN FIRMS AND PROPENSITY OF INDIVIDUALS STARTING NEW BUSINESSES}

\section{INTRODUCTION}

A major question in the social sciences and in the entrepreneurship literatures is about how new businesses originate (Romanelli and Schoonhoven, 2001). New businesses are important since they contribute to economic growth by replacing businesses that have failed, by creating jobs and by converting new technologies into products and services (Shane, 2000). Due to the importance of this question, a growing body of research has examined the antecedents to entrepreneurial start-ups (Watson et al., 1998), including psychological attributes (Carter et al., 2003; McCarthy, 1998, 1999), demographic factors (Robinson and Sexton, 1994), role models (Katz, 1992), industry characteristics (Dean and Meyer, 1996) and geographical location (Romanelli and Schoonhoven, 2001).

More recently, researchers have started to examine how knowledge gained from individual experiences leads to the recognition of opportunities that forms the basis for opportunity exploitation (Shane, 2000; Venkataraman, 1997). Researchers have focused on prior knowledge gained from work experience since through work experiences individuals gain product and marketing ideas, develop networks of contacts (De Koning, 1999), and learn about market needs (Ardichvili et al., 2003). Therefore, a significant proportion of an entrepreneur's ideas for new businesses come from knowledge originating from earlier employment (Dahlstrand, 1997; Romanelli and Schoonhoven, 2001). For example, Shane (2000) found that 
in 7 out of the 8 companies he studied, ideas for the commercialization of the 3D technology came from prior experience, and founders of many IT-based companies discovered new opportunities from their specialized skills and experience gained in the field (Roberts, 1991).

Despite the importance of prior knowledge gained from work experience (Shane, 2000), little is known about the specific types of knowledge that lead to business founding. Our study contributes to the organizational founding literature by showing that knowledge associated with technological innovation activities in organizations relates to the propensity of individuals leaving the organizations to start new businesses. The study also adds to the opportunity recognition literature by showing that some types of knowledge, more so than others, are valuable for opportunity exploitation.

The next section develops the argument that product innovation leads to knowledge that can be more easily appropriated by the individual for commercial uses, whereas knowledge gained from process innovation must be integrated with other parts of the organization to be valuable. The third section describes the research methodology. The concluding section discusses the implications of this research to better understand how knowledge gained from past experiences shape opportunity recognition and exploitation.

\section{HYPOTHESES DEVELOPMENT}

The opportunity recognition process consists of the identification, evaluation and exploitation of business opportunities (Shane and Venkataraman, 2000). The present study is positioned within the successful exploitation of a business opportunity. By successful, we mean that the venture has been started but that does not necessarily mean that the venture is profitable or has attained positive cash flow. As noted by Carter et al. (2003), a new venture goes through a 
gestation period of about three years where the business becomes established and only after this gestation period might it be appropriate to evaluate a venture with bottom line outcomes such as profits and return on investments. Opportunity recognition can be a product of economic factors and industry factors such as the competitiveness of the industry (Delmar and Shane, 2004; Shepherd 1999), the growth rate of the product-market (Park and Bae, 2004), whether the product or service is to be sold in a developing or a developed economy (Park and Bae, 2004), the lead time necessary to bring the product or service to the market (Shepherd, 1999), the educational requirement needed to enter the industry (Shepherd, 1999), and the availability of financing such as venture capital financing (Gil and Morris, 2004). For instance, Haber and Reichel (in press) illustrated that the attractiveness of a tourism venture depends on factors such as the level of infrastructure and development and the presence of other tourism companies. Gil and Morris (2004) illustrated how the development of the venture capital industry in Israel contributed to the development of high-technology clusters in Israel. Social factors such as having close friends, or family members in business (Davidsson and Honig, 2003), informal industry networks comprising customers, suppliers and investors (Ozgen and Baron, in press), the presence of professional forums such as conferences and workshops and the presence of mentors (Ozgen and Baron, in press) also determine the level of opportunities available to potential entrepreneurs. This study adds to the opportunity recognition literature by including exposure to innovation activities in organizations as the nexus of opportunity exploitation.

In general, there are two broad motives that drive individuals to leave organizations to start their own businesses: push factors such as job dissatisfaction (Garvin, 1983; Shaver and Scott, 1991) and pull factors such as opportunity recognition (Dietrich and Gibson, 1990). By using the theoretical framework of opportunity recognition (Ardichvili et al., 2003; Eckhardt 
and Shane, 2003; Shane and Venkataraman, 2000; Venkataraman, 1997), this study focuses on opportunity as the basis for individuals leaving the organization. Shane (2000) and Shane and Venkataraman (2000) argued that the opportunity recognition process includes opportunity recognition and the development and exploitation of business ideas. Venkataraman (1997) and Shane and Venkataraman (2000) noted that the ability of individuals to recognize business opportunities depends on the level and nature of information possessed. At any one time, only some people will recognize a particular opportunity (Venkataraman, 1997). This is because the ability to recognize opportunities is related to the distribution of information in society (Eckardt and Shane, 2003; Jacobson, 1992; Kirzner, 1997). The Austrian theory contends that markets are made up of people who possess different levels of information, and the existence of this asymmetrical information allows some people but not others to recognize opportunities (Jacobson, 1992; Shane, 2000). While the opportunity recognition framework suggests that prior knowledge is the basis for discovering business opportunities, the literature is vague on the type of knowledge that leads to this discovery. The present study extends the literature on opportunity recognition by proposing that knowledge spillovers from innovative companies can increase the propensity of individuals starting new businesses and that some types of knowledge are more valuable than other types of knowledge for business founding.

Through an organization's innovative activities, employees develop specialized knowledge that enables them to recognize entrepreneurial opportunities (Venkataraman, 1997). By exploring ideas and by experimenting with different prototypes, employees are equipped with knowledge in product and technical specifications, as well as the commercialization opportunities of the innovation (Aldrich and Wiedenmayer, 1993). The influence of an organization's innovative activities on the propensities of its employees leaving to start their 
own businesses is probably best illustrated by the "Fairchild view" (Gompers et al., 2003). The "Fairchild view" has its origins from Fairchild Semiconductors, which was primarily an entrepreneurial and high-risk based organization founded by eight engineers who invented the first integrated circuit in 1959 (Gompers et al., 2003). These engineers departed from Shockley Semiconductor Laboratory, and with their knowledge and exposures at the firm, they founded Fairchild Semiconductor Corporation. The "Fairchild view" attributes employees' departure from their organizations to the knowledge and experience, which they have gained in the organizations. Between the years 1957-1976, at least 23 out of 67 entrants to the semiconductor industry had at least one founder who worked for Fairchild Semiconductors (Braun and Macdonald, 1982). The exposure and experience gained in Fairchild could be seen as a way for employees to recognize business opportunities.

Organizations that engaged in innovation activities usually deal simultaneously with multiple technologies within their existing product areas (Dahlstrand, 1997). These simultaneous multiple technologies may result in "research spillovers." Individuals who want to exploit these "spillovers" within the organization may not be able to do so as the opportunities may fall beyond the main stream of the organization's strategic focus (Chesbrough, 2003). Nevertheless, these misfits of research outputs provide potential for innovation exploitations external to the organization (Dahlstrand, 1997). Some new technologies are not exploited by organizations because the products do not meet the requirements of current customers. The opportunities created by these new technologies are then exploited by new businesses (Christensen, 1997; Dahlstrand, 1997). Thus, recognition of business opportunities through research spillovers can be a pull factor for employees to leave 
their organizations to start businesses (Garvin, 1983; Katz, 1992). We therefore hypothesize that:

Hypothesis 1: Technology-oriented organizations with higher levels of innovation activities are more likely to have employees leaving to start new businesses than technology-oriented organizations with lower levels of innovation activities.

\section{Product versus process innovation}

Despite the importance of knowledge as the basis for opportunity recognition and exploitation (Jacobson, 1992; Shane and Venkataran, 2000), there could be differences in the extent that knowledge can be transferred for commercial uses (von Hippel, 1998). This section develops the argument that product innovation leads to knowledge spillovers that are related to starting businesses. Product innovation is defined as developing new products or services to meet the needs of the external user or the needs of the market (Damanpour and Gopalakrishnan, 2001; Utterback and Abernathy, 1975), while process innovation is defined as developing a new or substantially improved production process through new equipment or reengineering of operational process (He and Wong, 2004; Wong and He, 2003).

Product innovations are targeted at the external customers and are primarily customerand market-driven (Utterback and Abernathy, 1975). The benefits derived from product innovations are observable because the revenues generated from successful product innovations are explicit in comparison to the monetary returns of process innovations, which are implicit and often represented by a reduction in manufacturing costs (Utterback and Abernathy, 1975). Furthermore, employees' involvements in product innovations may expose them to new markets and user needs (Damanpour and Gopalakrishnan, 2001). Close 
relationships between employees and lead users of a technology in the industry may also give rise to sources of ideas for new businesses (Dahlstrand, 1997; Lilien et al., 2002; Tidd and Bodley, 2002). Employees may be able to capitalize on these new ideas to start a new business to address an unfulfilled market need.

In contrast, the knowledge spillovers for business ideas from process innovation are lower as compared to product innovation. Based on the definition used in this study, process innovation has an internal focus, and the customers are end-users within the organizations who use and work with the new process (Damanpour and Gopalakrishnan, 2001). To be valuable, knowledge of specific innovation processes within the organization must often be integrated with other firm-specific resources for exploitation and implementation (Damanpour and Gopalakrishnan, 2001). Additionally, process innovations often consist of improved production processes that lead to production efficiencies (Damanpour and Gopalakrishnan, 2001) which enable organizations to charge lower prices. However, it is difficult for new businesses to benefit from production efficiencies due to the limited scale efficiencies of new businesses. Rather, new businesses often compete by providing products that are differentiated by functionality and priced at a premium (Churchill, 1997). Furthermore, the cost of implementing technological process innovations can be high since it sometimes requires expenditure for state of the art equipment. New businesses are usually strapped for resources (Stevenson and Jarillo, 1990) and may not have the capital to invest in this equipment.

Based on the knowledge-based view of product and process innovations, it has been established that the knowledge associated with process innovations is difficult to comprehend, and cannot be easily understood or copied by others (Gopalakrishnan et al., 1999). This is because knowledge affiliated to process innovations is less observable than knowledge 
affiliated to product innovations as process innovations are related to the production and delivery of outcomes and not the outcomes themselves. Moreover, the knowledge attached to process innovations is relatively more complex because it is interrelated to other sub-systems of the organization (Lippman and Rumelt, 1982). To exploit this knowledge, a thorough understanding of how the process works in a specific organization is required. It is usually difficult for competitors to imitate and emulate technological process innovations because knowledge associated to these innovations is exclusive and firm specific (Levin et al., 1987). An employee who gains process knowledge might be less inclined to leave his or her organization because the knowledge gained is more useful inside the organization than outside of it (Meyer and Allen, 1991). The acquisition of process innovation knowledge, which is firmspecific, may increase the employee's opportunity costs of leaving the organization. The above consideration leads us to the following hypotheses.

Hypothesis 2: Product innovation is positively related to the likelihood of employees leaving technology-oriented organizations to start new businesses.

Hypothesis 3: Process innovation is negatively related to the likelihood of employees leaving technology-oriented organizations to start new businesses. 


\section{RESEARCH METHOD}

\section{Sample}

Data for this study were drawn from the National Innovation Survey jointly conducted in 2000 by the Economic Development Board (EDB) of Singapore and the National University of Singapore (NUS) Entrepreneurship Centre. Although the study was based on firms in Singapore, the results might be generalizable to other developed countries, particularly among OECD countries. A cosmopolitan country with high influx of foreign multinational corporations (MNCs), Singapore is comparable to other developed countries like the US and EU in terms of technological development and R\&D advancement. Empirical studies on national innovation have found that Singapore achieved a significantly rapid technological industrial growth in comparison to other developing countries (Wong, 2002). Singapore's R\&D expenditure for manufacturing businesses is also comparatively ranked with other OECD countries (OECD, 2001). The sampling frame consist of 1,872 manufacturing firms, representing more than twothirds of the four major manufacturing clusters in Singapore: electronics, chemicals, precision and process engineering, and transport engineering. The samples were obtained from EDB's Census of Industrial Production 1997 by excluding firms with less than five employees. Although we surveyed only manufacturing firms, the firms produced almost equal amounts of product and process innovations. For instance, (a) $11 \%$ of the manufacturing firms surveyed indicated that they introduced into the market process innovations over the last 3 years as compared to $12 \%$ who indicated that they introduced product innovations; and (b) $23 \%$ of firms indicated that $10 \%$ or more of their production volume used new/improved processes over the last 3 years as compared to $23 \%$ who reported that $10 \%$ or more of their annual sales consist of 
new/improved products introduced over the last 3 years. In summary, the manufacturing firms in our sample have engaged in comparative levels of product and process innovations.

Questionnaires were sent to the CEOs of 1,872 manufacturing firms. A total of 371 CEOs completed the questionnaires, yielding a $19.8 \%$ response rate. Missing data and doubtful responses were clarified by telephone calls and in some cases, removed from the sample. Respondents and non-respondents were comparable in terms of age, foreign-ownership, firm size, and manufacturing cluster. Possible non-response bias was examined by comparing the demographic characteristics of respondents $(n=371)$ with those of non-respondents $(n=$ 1,501). One-way between group analysis of variance (ANOVA) of age, number of employees, foreign-ownership and manufacturing clusters resulted in a statistically non-significant $\mathrm{F}$ of 0.52 for age $(\mathrm{p}=0.39)$; non-significant $\mathrm{F}$ of 0.35 for number of employees $(\mathrm{p}=0.45)$; nonsignificant $\mathrm{F}$ of 0.96 for foreign-ownership ( $\mathrm{p}=0.89$ ); and non-significant $\mathrm{F}$ of $0.83,0.71,0.79$ and 0.69 respectively for electronics, chemicals, precision and process engineering, and transportation engineering firms respectively $(\mathrm{p}=0.57, \mathrm{p}=0.49, \mathrm{p}=0.63$, and $\mathrm{p}=0.39)$. Of the 371 valid responses, 145 (39 percent) of the organizations were considered as innovating organizations and 226 (61 percent) as non-innovating organizations. Following the widely accepted definitions of innovation used by OECD (OECD-Eurostat 1997) and adopted by existing studies (e.g., He and Wong, 2004; Wong and He, 2003), organizations were regarded as innovating if they introduced to the market at least one of the following during the last three years: (1) product innovation (substantial improvement of a current product or development and manufacture of a product which is new to the business); and (2) process innovation (substantially improved or new production process through the introduction of new process equipment or re-engineering of an operational process). 


\section{Data analysis method}

We were interested in predicting the effects of firms' innovation activities on the number of spin-off businesses started by ex-employees. However, the dependent or endogenous variable was a discrete, non-negative count data that was highly skewed and heteroscedastic. The numerical value for "skewness" was 3.98 and the F-statistic for the Goldfeld-Quandt heteroscedasticity test was significant at $\left.0.1 \%\left(F_{137,137}=3.79\right)\right)$, indicating the presence of heteroscedasticity. In addition, the mean value for number of start-ups (0.35) is larger than the median value (0.00). While a non-linear procedure such as Poisson regression seemed appropriate to deal with the heteroscedastic and skewed distribution of nonnegative count data, a Poisson model assumes that the mean and variance of the dependent variable are equal. However, we found that our data violated this assumption as the variance of our dependent variable (1.30) was larger than the mean (0.35) resulting in an over dispersion of the data. Instead of a Poisson regression, we used the negative binomial distribution to predict the number of businesses started by ex-employee. The negative binomial distribution allows the introduction of an error term in the regression to correct the problem of over dispersion in the data (Bowman and Narayandas, 2001).

In addition to predicting the number of new businesses started by ex-employees, we were also interested to examine if the coefficients of the predictor variables were significantly related to the propensity of employees starting new businesses. The dependent variable here was represented by a dichotomous value of "0" (no knowledge of new businesses started by ex-employees) and "1" (knowledge of new businesses started by ex-employees). We used logit regressions to test the significance of the predictors on the binary dependent variable. 


\section{Dependent variable}

Our study focused on 2 dependent variables. The first was the count of new businesses started by ex-employees of the respondent's firm. This variable was measured by asking the respondent CEO the number of start-up companies by ex-employees in Singapore in the last 3 years that employed similar technology as the respondent's firm. The second dependent variable was the propensity of start-up companies by ex-employees. This was a dichotomous variable coded as " 0 " for no knowledge of start-up by ex-employees and " 1 " knowledge of start-up by ex-employees. Appendix 1 provides the list of questionnaire items and its operationalizations.

\section{Independent variables}

The three independent variables in this study were innovation, product innovation, and process innovation. Innovation was represented by a dummy variable; 1 if the organization had introduced at least one of the following over the last three years: (1) a product new to the business or a substantially improved product (product innovation); (2) a new or substantially improved production process through new equipment or re-engineering of operational process (process innovation), 0 if otherwise. Product innovation intensity referred to the percentage of total annual sales from new or improved products introduced over the last three years, while process innovation intensity referred to the percentage of production volume using new or improved processes introduced over the last three years.

\section{INSERT TABLE 1 ABOUT HERE}




\section{Control variables}

This paper examines the relationship between organizational innovation activities and the number of new businesses started by ex-employees. We used variables such as industry dummies, firm size, foreign ownership, government-linked status, sales growth rate, and the Herfindahl-Hirschman Index (HHI) as controls in our analyses. Due to different technological dynamism (e.g., technological opportunity, appropriability regimes) inherent in different industries, industrial sectors play an influential role in determining the level of organization innovation (Cohen and Levin, 1989). Manufacturing clusters such as electronics, chemicals, process and precision engineering, and transportation engineering (reference category) were used as industry dummies because they constituted the four largest and most important manufacturing sectors in Singapore (Wong, et al., 2003). It has been long observed that innovation is correlated to firm's size; the larger the firm, the higher the number of innovations it generates (Fritsch and Meschede, 2001). One measure of firm's size is the total number of employees in the firm. The common proposition is that the number of innovators increases with employment size (Cohen and Steven, 1996; Fritsch and Meschede, 2001). To compensate for skewness, the firm's size was represented by the log of total employment in 1999.

Singapore is well-known for its high influx of foreign MNCs into the country. These MNCs are resource rich, have better international innovation networks, and are more likely to engage in innovation and $R \& D$ related activities than local firms (Janne, 2002). Foreign ownership was represented by a dichotomous variable, 1 if foreign owned (<30\% local ownership), 0 if otherwise. Singapore's rapid technological development has until recently, been largely dependent on foreign MNCs. There have been increasing efforts by the Singapore government to support indigenous innovation and R\&D activities (Wong, 2001). Therefore, 
government-linked firms may engage in more innovation activities as compared to non government-linked firms. Government-linked status was a dichotomous variable taking the value of 1 if government linked and 0 otherwise. The literature also provides evidence on the link between innovation and sales growth, where innovative firms are more likely to experience increasing levels of sales growth (Rudma, 2001). This variable was measured by the compounded average sales growth rate from 1996-1999, with 1996 as the base year. High levels of market competitiveness have long been associated with entrepreneurial opportunities (Kirzner, 1973). We used the Herfindahl-Hirschman Index (HHI) as a proxy for the level of competition within each manufacturing sector. The HHI for the electronics, chemicals, process and precision engineering, and transportation engineering sectors were $0.42,0.31,0.05$, and 0.07 respectively.

\section{RESULTS}

Table 1 shows that 48 respondent CEOs (13\%) knew of start-up companies by exemployees and the reported number of new businesses by each of these 48 respondents ranged from 1 to $7.5 .4 \%$ or 20 of them reported that they each knew of 1 start-up company by exemployees, while 3 reported that they each knew of 7 start-up companies by ex-employees. For 2 to 6 new businesses reported by each CEO, the corresponding numbers were 9, 4, 5, 4 and 3 . In total, there were 129 new businesses that were formed by ex-employees of the respondents' firms. The respondents for our study were distributed along the 4 main manufacturing clusters in Singapore, with the majority from the process and precision engineering sector (54\%). Respondents' firm size was proxied by total employment ranged from less than 30 employees to more than 150 employees. $37 \%$ of our respondents were foreign-owned firms while $4 \%$ 
were government-linked firms. Most respondents (51\%) registered sales growth of less than $30 \%$ over the last 3 years while $21 \%$ reported negative sales growth. Average sales growth over the last 3 years varied from a low of $-42 \%$ to a high of $154 \%$. In terms of innovativeness, 145 firms (39\%) were classified as innovative with an average product and process innovation intensities of $30.25 \%$ and $33.1 \%$ respectively (please refer to descriptive statistics in Table 2). This means that on average, firms that engaged in product innovations had $30.25 \%$ of their total annual sales from new or improved products while firms that engaged in process innovations had on average $33.1 \%$ of their production volume from new or improved processes.

\section{INSERT TABLE 1 ABOUT HERE}

Table 2 shows the correlation values for the variables. As observed in Table 2, start-up propensity was significantly correlated with a government-linked company $(r=0.144, p<0.01)$ and with innovation $(\mathrm{r}=0.147, \mathrm{p}<0.01)$. Consistent with findings from existing literature on the influence of sales growth (Love and Roper, 1999), government-linked status (Chew and Chew, 2003), and electronics sector (Wong, 2002) on innovation, we found positive correlation between innovation and sales growth, government-linked status, and electronics sector. Both product and process innovations were significantly correlated with electronics, process and precision engineering, and government-linked status. The correlation coefficients among the variables were all below 0.60 (Kennedy, 1992) and none of the VIFs for the models was greater than 2, which was below the guideline of ten by Chatterjee and Price (1991). Thus it was unlikely that multicollinearity among the independent variables affected the findings. 


\section{INSERT TABLE 2 ABOUT HERE}

Table 3 presents the findings from the negative binomial regression analyses on the number of start-up companies in Singapore in the last three years by ex-employees. As observed in Model 1 of the full sample $(\mathrm{N}=371)$, which consisted of only control variables, the electronics sector $(p<0.05)$ and government-linked firms $(p<0.05)$ were closely related to the number of new businesses started by ex-employees. As mentioned, government-linked companies were likely to engage in innovation activities in response to the government's support for indigenous technological innovation. The organizations' focus on innovation might expose their employees to specialized knowledge that enabled them to recognize entrepreneurial opportunities. The findings in Model 1 also highlight that foreign ownership was negatively related to start-up propensity. Local firms were more likely than foreign-owned firms to experience employees leaving to start their own businesses. A possible explanation is that employees of foreign-owned firms are faced with higher opportunity costs when they leave their employments. Foreign firms usually offer better fringe benefits and more lucrative remuneration packages to their employees in comparison to local firms. These perks may deter employees of foreign firms to go into self-employment (Dyer, 1994). In addition, foreignowned firms tend to have more effective intellectual property (IP) protection policies, which make it harder for employees to appropriate any knowledge spillovers (Brouwer and Kleinknecht, 1999).

INSERT TABLE 3 ABOUT HERE 
Hypothesis 1 was tested in Model 2, where the innovation variable was incorporated in the regression analysis. The results in Model 2 supported hypothesis 1: organizations with higher levels of innovation activities were more likely to have employees leaving to start new businesses than organizations with lower levels of innovation activities. Innovation was significant at the $5 \%$ level with a coefficient value of 1.172 . The significance of the control variables in Model 2 remained unchanged. Model 2 explained about 16\% of the variance in the dependent variable and had a log-likelihood value of $707.23(\mathrm{p}<0.001)$. Hypothesis 2 and 3 were tested in Model 3, where both product and process innovation intensities were included in the regression model. The pseudo $\mathrm{R}^{2}$ increased to about $28 \%$ and the results for the control variables were consistent with Models 1 and 2. While product innovation intensity was positively related to the dependent variable $(b=0.8466, p<0.05)$, process innovation intensity was negatively related to the dependent variable $(b=-0.672, p<0.05)$. These findings provided support for hypothesis 2 that product innovation is positively related to the likelihood of employees leaving the organization to start new businesses, and also supported hypothesis 3 that process innovation is negatively related to the likelihood of employees leaving the organization to start new businesses. Essentially, the results in Model 3 supported the assertions that knowledge spillovers from product innovation compared to the knowledge spillovers from process innovation are positively related to business founding. To test the robustness of our results, we employed the negative binomial regressions on the sub-sample of 145 innovative firms. The findings of the sub-sample analysis found support for both hypotheses 2 and 3 . Product $(b=1.035)$ and process $(b=-0.906)$ innovation intensities were statistically significant at the 0.05 level, as compared to the full sample analyses. However, the pseudo $\mathrm{R}^{2}$ for the innovative sample was slightly higher at 0.35 . 
The findings from the logit regression on whether or not the respondent CEO knew of start-up companies by ex-employees are presented in Table 4. Although all variables that were significant in the negative binomial regressions were also significant in the logit regressions, variables such as process and precision sector, government-linked status, and sales growth rate had higher statistical significance in the logit regressions. The independent variables had the greatest predictive power of whether a respondent CEO knew of a start-up company by exemployees. The odds ratios in Table 4 indicated that a respondent whose firm had engaged in innovation was almost 4 times as likely to report start-up companies by ex-employees. While firms that engaged in product innovation were almost 3 times as likely to experience employees leaving to start new businesses, firms that engaged in process innovation were 2 times less likely to experience employees leaving. Consistent with the results of the negative binomial regression analyses, the results of the logit regressions provided strong support for all the hypotheses.

\section{INSERT TABLE 4 ABOUT HERE}

The electronics, process and precision engineering, sales growth, and government-linked status variables all had significant effects with $\mathrm{p}$ values $<0.05$ on the likelihood of employees leaving to start new businesses; all the odds ratios clustered around the value of 1.5 , indicating a one unit change in these variables increases the odds of business start-up by a factor of 1.5 . The logistic regression equation was statistically significant $(\mathrm{p}<0.01)$ with $31 \%$ of the variance explained. The effects of other control variables such as chemicals, foreign-ownership, firm size, and the HHI on the propensity of employees leaving to start new businesses were not significant. 


\section{DISCUSSION}

This study addressed the question of the technological innovation activities in an organization that make it more likely for someone from the organization to leave to start a new business. This question is intriguing because prior knowledge gained from the individuals' experiences, including work experience form the basis for opportunity recognition (Shane, 2000). Yet, little is known about the types of knowledge from work experiences that are valuable for individuals to discover and exploit business opportunities. This study shows that while innovation activities in the organization are related to opportunity exploitation, this relationship is positive only for some types of innovation activities. In particular, organizations with product innovation activities were positively associated with a greater likelihood of having someone leaving to start new businesses. In contrast, organizations with process innovation activities had lower propensities of employees leaving to start new businesses.

While the latter finding may seem counterintuitive since knowledge is assumed to be beneficial for opportunity recognition (Shane and Venkataraman, 2000), the earlier sections of this paper explain that the knowledge gained in process innovation tends to be firm specific. Having these specific skills may discourage someone from leaving the organization to start a new business since the knowledge acquired may have less value outside the organization than within the organization. Furthermore, unlike product innovations, which are usually patented so the bulk of the knowledge of their functionality reside in the public domain, innovations related to manufacturing processes are often protected via trade secrets, where the details are highly

confidential and the information is divulged to only a few people (Anton and Yao, 2002). 
Hence, it would be very difficult both technologically and legally to copy or appropriate that type of knowledge.

The finding that process innovation was related to lower propensity of individuals leaving raises a point that has not been addressed in the opportunity recognition literature that is, some experiences may lead to negligible or no opportunity exploitation. Furthermore, another issue that has not been addressed in the opportunity recognition literature is the "stickiness" of knowledge. Von Hippel (1998) argued that innovation happens at the location where knowledge is sticky. By that he means that innovation occurs where the knowledge is more tacit and difficult to transfer. For example, he illustrated that IC circuits can be designed by either the manufacturer or the user of the chip, and the side with more "sticky" knowledge is likely to do the innovation.

Our finding raises the point that stickiness can also be viewed as the extent to which knowledge can be appropriated by individuals in an organization. In cases where knowledge relates to customers or to market needs (such as knowledge associated with technological product innovation), the individual may be able to appropriate that knowledge to his or her own advantage and exploit it to start a business. In other instances where knowledge has to be integrated with other parts of the organization (such as knowledge associated with technological process innovation), an individual's knowledge may be more valuable if it is used within the organization. 


\section{LIMITATIONS}

While the study finds support for the effects of product and process innovations on the propensity of individuals leaving their companies to start their own businesses, these findings must be read with caution as several limitations should be noted. Reverse causation could be an explanation for the findings. Individuals that are interested in starting new businesses seek organizations that constantly develop new products to learn from these organizations with a view to starting their own businesses in the future. Although this possibility cannot be ruled out in this study, it is perhaps more likely that individuals join organizations for other reasons such as the nature of the job and benefits provided (Furnham and Koritsas, 1990). Future studies can examine the reasons individuals join the organizations to rule out alternative explanations for the findings. Despite this possibility, encouraging organizations to be innovative is beneficial from a public policy perspective since this can result in knowledge spillover effects that help individuals in their new businesses.

Another limitation in this study is that we did not know the number of businesses that each ex-employee founded. It is possible that some ex-employees could have started more than one business after leaving their parent organizations. Future studies could contact the exemployees to track the businesses that they founded. Further, although generally most manufacturing-oriented firms are technologically oriented, not all are high-tech intensive. Our sample showed that only $39 \%$ of the firms engaged in some form of innovation, either product or process innovation or both types of innovation. In other words, the distribution of our sample consisted of both innovative and non-innovative firms. Future research should consider including 
firms from both the manufacturing and service sectors to have a wider coverage of all sectors to examine the effects of innovation activities on new venture formation.

Yet another limitation is that the study requires the respondent (CEO) to be aware of individuals leaving to start new businesses. There could be individuals who start new businesses without the CEO's knowledge. Despite this limitation, a benefit of this study's approach is that the new businesses could be competing in markets or using technology related to the organizations that the founders had worked for. In these cases, the knowledge spillovers could be related to the job experiences of the former employees. Another benefit of this approach is that the CEO is more likely to identify the significant businesses that were started. Future studies should examine the new businesses in greater depth to examine the extent these businesses utilize technologies and knowledge gained from the founders' experiences in their previous organizations. Finally, while this study examined successfully formed ventures, future research should also examine the nascent start-up activities of individuals in innovative companies, which may or may not result in new venture creation. Such a study may result in a better understanding of start-up activities as there is less left-censoring of the data (Foo, Sin and Yiong, 2006).

\section{CONCLUSION}

Future research could further explicate the relationships found in this study. It would be interesting to investigate the relationships among the characteristics of the parent organizations, such as the performance and quality of their technology and the performance of the businesses that their former employees start. For example, are employees from successful organizations also more likely to be successful entrepreneurs? It is possible that knowledge spillovers from successful organizations are more valuable than knowledge spillovers from less 
successful organizations. It is also possible that individuals may benefit more from experiences in smaller organizations than from larger organizations. In a small organization, individuals are involved in a greater range of activities relating to the technology and the market. In this way, it is more likely that they will have the bundle of knowledge required to recognize and exploit business opportunities.

Future research should examine the entrepreneurial propensities of individuals who work for highly innovative companies as it is possible that these innovative companies attract employees who are interested in entrepreneurial activities. This could create positive reinforcing loops such that highly innovative companies attract highly entrepreneurial individuals that in turn reinforce the innovativeness of the companies. Future research could also examine the effects of individuals leaving on the parent organizations. Having employees leave might be detrimental to the parent organizations as the new businesses can poach the organizations' customers. Alternatively, the effects could be positive if the start-ups produce products or services that complement the parent organizations' products and services. This enlightened self-interest could benefit both the organizations and individuals in the organizations. Finally, future research can examine the rate of employees leaving for new entrepreneurial activities as a function of the phase that the industry is in and the cost of entry to that industry. For example, in the late $60 \mathrm{~s}, 70 \mathrm{~s}$, and early 80 s, the semiconductor industry in Silicon Valley was rapidly expanding and the cost of entry was low (Assimakopoulos et al., 2003). Not surprisingly, many new ventures were formed during those periods.

From a practical standpoint, our study elucidates that individuals who are interested in creating technology-related ventures can benefit by first working for organizations that focus on innovation. The organizations' innovative activities may result in knowledge spillovers that 
can help individuals discover business opportunities. The findings further suggest that individuals will benefit more by working for organizations that focus on product innovations. By working for organizations such as $3 \mathrm{M}$, individuals gain knowledge of the technology and also of market needs that can help them discover new business opportunities.

This study focuses on employees leaving the organization to start new businesses. By leaving, organizations lose some of the knowledge benefits that the organizations had a part in creating. Current research shows that organizations can tap some of these knowledge benefits by spinning off new businesses (Christensen, 1997). In this way, individuals with the knowledge gained from the organization can be designated to head the spin-offs, and the parent organization can support them with financial and human resources. The findings from this study suggest that developing mechanisms for organizational spin-offs may be even more important for organizations that focus on product innovations than for organizations that focus on process innovations. Moreover, encouraging spin-offs can overcome a dilemma highlighted by Christensen (1997). That is, at the early stages of a disruptive technology, some existing customers are not willing to adopt the new technology and as a result organizations do not exploit these technologies. As the new technology develops, existing organizations find themselves behind the technology trajectory. By spinning off new businesses, organizations can focus on their core technologies while still developing new technologies for other commercial purposes. We argued that a reason technological process innovation are less likely to have knowledge spillovers for business founding is that, for it to be useful, this knowledge requires a thorough understanding of the organization. If this explanation is correct, then organizations, particularly organizations that focus on process innovations may have technologies and innovations that are left under-developed. This creates redundancy in their 
technological investments. Organizations can help unlock some of the value of these technologies by forming teams, comprising of members from different departments in the organization to exploit these technologies either as a spin-off or find further ways to exploit the technologies within the organizations.

In summary, our paper highlights the significance of organizations' technological activities on the propensity of individuals leaving the organizations to start new businesses. Our study reveals that innovative organizations are more likely than non-innovative organizations to have individuals leaving to start new businesses. This propensity is greater for organizations that focus on product innovation than for those that focus on process innovation. We discuss how knowledge spillovers from innovation explain these findings. Future work on opportunity recognition should examine how knowledge spillovers can shape the extent to which opportunities are recognized and exploited. 


\section{REFERENCES}

Aldrich, H.E., and Wiedenmayer, G. 1993. From traits to rates: An ecological perspective on organizational foundings. Advances in Entrepreneurship, Firm Emergence, and Growth, 1: 145-195. Greenwich, Conn.: JAI Press.

Anton, J.J., and Yao, D.A. 2005. Little patents and big secrets: managing intellectual property. The Rand Journal of Economics, 35 (1): 1-22.

Ardichvili, A., Cardozo, R., and Ray, S. 2003. A theory of entrepreneurial opportunity identification and development. Journal of Business Venturing, 18: 105-123.

Assimakopoulos, D., Everton, S., and Tsutsui, K. 2003. The semiconductor community in the Silicon Valley: A network analysis of the SEMI genealogy chart (1947-1986). International Journal of Technology Management, 25(1/2): 181-199.

Bowman, D., and Narayandas, D. 2001. Managing Customer-Initiated Contacts with Manufacturers: The Impact on Share of Category Requirements and Word-of-Mouth Behavior. Journal of Marketing Research, 38: 281-97.

Braun, E., and Macdonald, S. 1982. Revolution in Miniature: The History and Impact of Semiconductor Electronics. Cambridge: Cambridge University Press.

Brouwer E., and Kleinknecht A. 1999. Innovative output, and a firm's propensity to patent. An exploration of CIS micro data. Research Policy 28(6): 615-624.

Carter, N. M., Gartner, W. B., Shaver, K. G., and Gatewood, E. J. 2003. The career reasons of nascent entrepreneurs, Journal of Business Venturing, 18: 13-39.

Chatterjee, S., and Price, B. 1991. Regression analysis by example. New York: Wiley. 
Chesbrough, H. 2003. The governance and performance of Xerox's technology spin-off companies. Research Policy, 32: 403-421.

Chew, S.B., and Chew, R. 2003. Promoting innovation in Singapore: changing the mindset. International Journal of Entrepreneurship and Innovation Management 3(3): 249 - 266.

Christensen, C. 1997. The Innovator's Dilemma: When New Technologies Cause Great Firms to Fail. Harvard Business School Press: Boston.

Churchill, N.C. 1997. The six key phases of company growth. In S. Birley and D.F. Muzyka (Eds.), Mastering Enterprise, Pitman Publishing, 213-219.

Cohen, W., and Steven, K. 1996. Firm Size and the Nature of Innovation Within Industries: The Case of Process and Product R\&D, The Review of Economics and Statistics 78: 232- 243.

Cohen, W., and Levin, R. 1989. Empirical studies of innovation and market structure. In R. Schmalensee and R. D. Willig (Eds.), Handbook of Industrial Organization, Elsevier Science Publishers, Amsterdam, 1059-1107.

Davidsson, P., and Honig, P. 2003. The role of social capital and human capital among nascent entrepreneurs, Journal of Business Venturing, 18: 301-331.

Dahlstrand, A.L. 1997. Entrepreneurial spin-off enterprises in Goteborg, Sweden. European Planning Studies, 5(5): 659-673.

Damanpour, F., and Gopalakrishnan, S. 2001. The dynamics of the adoption of product and process innovations in organizations. Journal of Management Studies, 38(1): 45-69.

De Koning, A. 1999. Conceptualising opportunity recognition as a socio-cognitive process. Centre for Advanced Studies in Leadership, Stockholm. 
Dean, T. G., and Meyer, G. 1996. Industry environments and new venture formations in U.S. manufacturing: A conceptual and empirical analysis of demand characteristics. Journal of Business Venturing, 11(2): 107-132.

Delmar, F., and Shane, S. 2004. Legitimating first: Organizing activities and the survival of new ventures. Journal of Business Venturing, 19: 385-410.

Dietrich, G.B., and Gibson, D.V. 1990. New business ventures: The spin-out process. In Williams, F., Gibson, D.V. (Eds.), Technology Transfer- A Communication Perspective. SAGE Publications.

Dyer, W.G., J.R. 1994. Toward a theory of entrepreneurial careers. Entrepreneurship Theory and Practice, 19(2): 7-21.

Eckhardt, J. T., and Shane, S. A. 2003. Opportunities and entrepreneurship. Journal of Management, 29(3): 333-349.

Foo, M.D., Sin, H.P., and Yiong, L.P. 2006. Effects of team inputs and intrateam processes on new venture team effectiveness. Strategic Management Journal, 27: 389-399.

Fritsch, M., and Meschede, M. 2001. Product innovation, process innovation and size. Review of Industrial Organization, 19(3): 335-350.

Furnham, A., and Koritsas, E. 1990. The Protestant work ethic and vocational preference. Journal of Organizational Behaviour, 11: 43-55.

Garvin, D.A. 1983. Spin-Offs and the new firm formation process. California Management Review, 25(2): 3-20.

Gil, A. and Morris, T. 2004. Venture capital start-up co-evolution and the emergence and development of Israel's new high tech cluster. Economics of Innovation and New Technology, 13: 33-60. 
Gompers, P., Lerner, and J., Scharfstein, D. 2003. Entrepreneurial Spawning: Public

Corporations and the Genesis of New Ventures, 1986-1999. National Bureau of Economic Research. Massachusetts, Cambridge.

Gopalakrishnan, S., Bierley, P., and Kessler, E.H. 1999. A reexamination of product and process innovations using a knowledge-based view. The Journal of High Technology Management Research, 10(1): 147-166.

Haber, S., and Reichel, A. (in press). The cumulative nature of the entrepreneurial process: The contribution of human capital, planning and environment resources to small venture performance. Journal of Business Venturing.

He, Z.L., and Wong, P.K. 2004. Exploration vs. exploitation: An empirical test of the ambidexterity hypothesis. Organization Science, 15(4): 481-494.

Jacobson, R. 1992. The Austrian school of strategy. Academy of Management Review, 17(4): $782-807$.

Janne, O.E.M. 2002. The emergence of corporate integrated innovation systems across regions: The case of the chemical and pharmaceutical industry in Germany, the UK, and Belgium. Journal of International Management, 8(1): 97-119.

Katz, J.A. 1992. A psychological cognitive model of employment status choice. Entrepreneurship Theory and Practice, 17(1): 29-37.

Kennedy, P. 1992. A Guide to Econometric Methods, MIT Press, Cambridge, M.A.

Kirzner, I.M. 1973. Competition \& Entrepreneurship. Chicago: University of Chicago Press.

Kirzner, I. 1997. Entrepreneurial discovery and the competitive market process: An Austrian approach. Journal of Economic Literature, 35: 60-85. 
Levin, R., Klevorick, A., Nelson, R., and Winter, S. 1987. Appropriating the returns from industrial research and development. Brookings Papers on Economic Activity, 3:783820.

Lilien, G.L., Morrison, P.D., Searls, K., Sonnack, M. and Von Hippel, E. 2002. Performance assessment of the lead user idea-generation process for new product development. Journal of Marketing Research, 48(8): 1042-1059.

Lippman, S.A., and Rumelt, R.P. 1982. Uncertain imitability: An analysis of interfirm differences in efficiency under competition. Bell Journal of Economics, 13: 418-438.

Love, J.H., and Roper, S. 1999. The Determinants of Innovation: R \& D, Technology Transfer and Networking Effects. Review of Industrial Organization 15(1): 43-64.

McCarthy, Brenda. 1998/1999. The entrepreneur, risk perception and change overtime: A typology approach. IBAR, Dublin, 19/20(1): 126-140.

Meyer, J., and Allen, N. 1991. A three-component conceptualization of organizational commitment. Human Resource Management Review, 1(1): 61-89.

OECD. 2001. Science, Technology and Innovation Outlook. OECD, Paris.

OECD-EUROSTAT 1997. Proposed Guidelines for Collecting and Interpreting Technological Innovation Data, Oslo Manual, $2^{\text {nd }}$ edition, OECD, Paris.

Ozgen, E., and Baron, R.A. in press. Social sources of information in opportunity recognition: Effects of mentors, industry networks, and professional forums. Journal of Business Venturing.

Park, S., and Bae, Z. 2004. New venture strategies in a developing country: Identifying a typology and examining growth patterns through case studies. Journal of Business Venturing, 19: 81-105. 
Roberts, E.B. 1991. Entrepreneurs in high technology: lessons from MIT and beyond. New York: Oxford University Press.

Robinson, P.B., \& Sexton, E.A. 1994. The effect of education and experience on selfemployment success. Journal of Business Venturing, 9(2): 141-156.

Romanelli, E., and Schoonhoven, C.B. 2001. The local origins of new firms, in Schoonhoven, C.B and Romanelli, E. (Eds.), The Entrepreneurship Dynamic, Origins of Entrepreneurship and the Evolution of Industries. Stanford University Press.

Rudma, S.T. 2001. Are successful innovators high performers? Insights from Israel's largest companies. Academy of Management Executive, 15(1): 149-150.

Shane, S. 2000. Prior knowledge and the discovery of entrepreneurial opportunities. Organizational Science 11(4): 448-169.

Shane, S., and Venkataraman, S. 2000. The promise of entrepreneurship as a field of research. Academy of Management Review, 25:217-226.

Shaver, K. G., and Scott, L. R. 1991. Person, process, choice: The psychology of new venture creation. Entrepreneurship Theory \& Practice, 91(16): 23-45.

Shepherd., D. A. 1999. Venture capitalists' assessment of new venture survival. Management Science, 45: 621-632.

Stevenson, H.H., and Jarillo, J.L. 1990. A paradigm of entrepreneurship. Strategic Management Journal, 11: 17-27.

Tidd, J., and Bodley, K. 2002. The influence of project novelty on the new product development process. $R \& D$ Management, 32(2): 127-138.

Utterback, J.M., and Abernathy, W.L. 1975. A dynamic model of process and product innovation. Omega, 3: 639-656. 
Venkataraman, S. 1997. The distinctive domain of entrepreneurship research: An editor's perspective. In J. Katz and R. Brockhaus (Eds.), Advances in Entrepreneurship, Firm Emergence and Growth. JAI Press, Greenwich, CT.

Von Hippel, E. 1998. Economics of product development by users: The impact of sticky local information. Management Science, 44(5): 629-644.

Watson, K., Hogarth-Scott, S., and Wilson, N. 1998. Small business start-ups: Success factors and support implications. International Journal of Entrepreneurial Behaviour and Research, Bradford, 4(3): 217-238.

Wong, P.K. 2001. Leveraging multinational corporations, fostering technopreneurship: The changing role of S\&T policy in Singapore. International Journal of Technology Management, 22(5/6): 539-567.

Wong, P.K. 2002. From using to creating technology: The evolution of Singapore's National Innovation System and the changing role of public policy. In S. Lall and S. Urata (Eds.), Technology Policy in East Asia, World Bank and Elgar Press.

Wong, P.K., and He, Z.L. 2003. The moderating effect of a firm's internal climate for innovation on the impact of public R\&D support programs", International Journal of Entrepreneurship and Innovation Management 3(5/6), 525-545.

Wong, P.K., Kiese, M., Singh, A., and Wong, F. 2003. The pattern of innovation in Singapore's manufacturing sector. Singapore Management Review 25(1): 1-34. 


\section{TABLE I}

Frequency Distribution and Descriptive Statistics of Variables $(\mathrm{N}=371)$

\begin{tabular}{|c|c|c|c|c|c|c|c|c|c|c|c|}
\hline Variables & $\%$ & Mean & S.D & Min. & Max. & & $\%$ & Mean & S.D & Min. & Max. \\
\hline Start-up & & 0.13 & 0.33 & 0 & 1 & \multicolumn{2}{|c|}{ Product Innovation Intensity $(N=145)$} & 30.25 & 24.74 & 5.72 & 83.5 \\
\hline Yes & 13.0 & & & & & \multirow{5}{*}{\multicolumn{2}{|c|}{$\begin{array}{lc}\text { Less than } 10 \% & 28.6 \\
10 \%-24 \% & 30.4 \\
25 \%-49 \% & 19.6 \\
50 \%-74 \% & 9.8 \\
75 \% \text { and above } & 11.6\end{array}$}} & & & & \\
\hline No & 87.0 & & & & & & & & & & \\
\hline Start-up (count data) & & 0.35 & 1.14 & 0 & 7 & & & & & & \\
\hline 0 & 87.1 & & & & & & & & & & \\
\hline 1 & 5.4 & & & & & & & & & & \\
\hline 2 & 2.4 & & & & & \multicolumn{2}{|c|}{ Process Innovation Intensity $(N=143)$} & 33.1 & 30.07 & 7.81 & 84.6 \\
\hline 3 & 1.1 & & & & & Less than $10 \%$ & 20.6 & & & & \\
\hline 4 & 1.3 & & & & & $10 \%-24 \%$ & 25.2 & & & & \\
\hline 5 & 1.1 & & & & & $25 \%-49 \%$ & 18.7 & & & & \\
\hline 6 & 0.8 & & & & & $50 \%-74 \%$ & 11.2 & & & & \\
\hline 7 & 0.8 & & & & & $75 \%$ and above & 24.3 & & & & \\
\hline Industry & & & & & & \multicolumn{2}{|l|}{ Firm size (number of employees) } & 51.25 & 48.61 & 4.0 & 2026 \\
\hline Electronics & 11.0 & 0.11 & 0.31 & 0 & 1.0 & 30 or less & 35.6 & & & & \\
\hline Chemicals & 19.0 & 0.19 & 0.39 & 0 & 1.0 & $31-60$ & 16.2 & & & & \\
\hline Precision and & & & & & & $61-90$ & 11.3 & & & & \\
\hline Process Engineering & 54.0 & 0.54 & 0.3 & 0 & 1.0 & $91-120$ & 6.5 & & & & \\
\hline Transportation Engineering & 16.0 & 0.16 & 0.38 & 0 & 1.0 & $121-150$ & 4.0 & & & & \\
\hline Foreign firm & & 0.37 & 0.48 & 0 & 1.0 & 151 or more & 26.4 & & & & \\
\hline Yes & 37.0 & & & & & \multicolumn{2}{|l|}{ Government-linked firm } & 0.04 & 0.2 & 0 & 1 \\
\hline No & 63.0 & & & & & \multirow{2}{*}{\multicolumn{2}{|c|}{$\begin{array}{c}4.0 \\
96.0\end{array}$}} & & & & \\
\hline Innovation & & 0.39 & 0.49 & 0 & 1.0 & & & & & & \\
\hline Yes & 39.0 & & & & & \multirow{10}{*}{$\begin{array}{l}\text { Herfindahl index } \\
\text { Electronics } \\
\text { Chemicals } \\
\text { Process and precision engineering } \\
\text { Transport engineering }\end{array}$} & & \multirow[t]{10}{*}{0.21} & \multirow[t]{10}{*}{0.18} & \multirow[t]{10}{*}{0.05} & \multirow[t]{10}{*}{0.42} \\
\hline No & 61.0 & & & & & & 0.42 & & & & \\
\hline Sales Growth & & 17.23 & 22.46 & -42 & 154 & & 0.31 & & & & \\
\hline$<0 \%$ & 21.0 & & & & & & 0.05 & & & & \\
\hline $0-<5 \%$ & 14.0 & & & & & & 0.07 & & & & \\
\hline $5-<10 \%$ & 9.0 & & & & & & & & & & \\
\hline $10-<20 \%$ & 13.0 & & & & & & & & & & \\
\hline $20-<30 \%$ & 15.0 & & & & & & & & & & \\
\hline $30-<40 \%$ & 10.0 & & & & & & & & & & \\
\hline $40 \%$ or more & 18.0 & & & & & & & & & & \\
\hline
\end{tabular}




\section{TABLE II}

Correlation of Variables $(\mathrm{N}=371)$

\begin{tabular}{|c|c|c|c|c|c|c|c|c|c|c|c|c|c|}
\hline & 1 & 2 & 3 & 4 & 5 & 6 & 7 & 8 & 9 & 10 & 11 & 12 & 13 \\
\hline 1.Start-up & 1 & & & & & & & & & & & & \\
\hline 2.Electronics & 0.003 & 1 & & & & & & & & & & & \\
\hline 3.Chemicals & 0.019 & $\begin{array}{c}- \\
0.166^{*} * * \\
\end{array}$ & 1 & & & & & & & & & & \\
\hline $\begin{array}{l}\text { 4.Process and precision } \\
\text { engineering }\end{array}$ & 0.028 & $\begin{array}{c}- \\
0.380 * * \\
\end{array}$ & $-0.523 * *$ & 1 & & & & & & & & & \\
\hline 5.Transport Engineering & 0.030 & $\begin{array}{c}- \\
0.153 * * \\
\end{array}$ & $-0.155^{* *}$ & $-0.211 * *$ & 1 & & & & & & & & \\
\hline 6.Foreign & -0.066 & $0.150 *$ & $0.111^{*}$ & $-0.113 *$ & -0.066 & 1 & & & & & & & \\
\hline 7.Firm size & 0.031 & $0.355 * *$ & -0.010 & $-0.231 * *$ & 0.014 & $0.244 * *$ & 1 & & & & & & \\
\hline 8.Government-linked & $0.144 * *$ & 0.012 & -0.067 & -0.072 & -0.026 & $-0.162 * *$ & $0.160^{*}$ & 1 & & & & & \\
\hline 9.Sales growth rate & 0.069 & $0.138 * *$ & 0.052 & $-0.116^{*}$ & -0.013 & -0.003 & $0.114 *$ & 0.021 & 1 & & & & \\
\hline 10.Innovation & $0.147 * *$ & $0.256 * *$ & 0.071 & $0.144 *$ & 0.075 & 0.072 & 0.085 & $0.183 * *$ & $0.093 *$ & 1 & & & \\
\hline \begin{tabular}{|l|} 
11.Product innovation \\
intensity $(\mathrm{N}=145)$
\end{tabular} & 0.079 & $0.208 * *$ & 0.033 & $-0.122 *$ & 0.062 & 0.021 & 0.089 & $0.132 *$ & 0.085 & $0.551 * *$ & 1 & & \\
\hline \begin{tabular}{|l|l|} 
12.Process innovation \\
intensity $(\mathrm{N}=143)$
\end{tabular} & -0.025 & $0.265 * *$ & -0.013 & $-0.102 *$ & 0.062 & 0.018 & 0.077 & $0.101^{*}$ & 0.074 & $0.593 * *$ & $0.501 * *$ & 1 & \\
\hline 13. Herfindahl index & -0.098 & 0.083 & 0.084 & -0.077 & -0.088 & 0.021 & 0.018 & 0.040 & 0.056 & 0.022 & 0.032 & 0.041 & 1 \\
\hline
\end{tabular}

$* * \mathrm{p}<.01 ; * \mathrm{p}<.05$. All tests are two-tailed.

Note: Correlations between electronics, chemicals, process and precision engineering, transport engineering, foreign, government-linked, and innovation are Cramers Phi while correlations between start-up, product innovation, process innovation, sales growth, firm size, and Herfindahl index are Pearson. Point biserial correlations are between the set of continuous variables (start-up, sales growth, product innovation, process innovation, firm size and Herfindahl index) and dichotomous variables (electronics, chemicals, process and precision engineering, transport engineering, foreign, government-linked, and innovation). 
TABLE III

Negative Binomial Regression Models Predicting the Number of Start-Up Companies by Ex-Employees

\begin{tabular}{|c|c|c|c|c|c|}
\hline & $\begin{array}{l}\text { Model 1: Controls } \\
\qquad(\mathbf{N}=\mathbf{3 7 1})\end{array}$ & $\begin{array}{l}\text { Model 2: Controls } \\
+ \text { Innovation }(\mathrm{N}= \\
\text { 371) }\end{array}$ & $\begin{array}{l}\text { Model 3: Controls + } \\
\text { Product and Process } \\
\text { Innovation } \\
\text { Intensities }(\mathbf{N}=\mathbf{3 7 1}) \\
\end{array}$ & $\begin{array}{l}\text { Model 1: Controls } \\
\qquad(N=145)\end{array}$ & $\begin{array}{l}\text { Model 2: Controls + Product and } \\
\text { Process Innovation Intensities } \\
(\mathbf{N}=\mathbf{1 4 5})\end{array}$ \\
\hline \multicolumn{6}{|l|}{ Model Indices } \\
\hline Pseudo $\mathrm{R}^{2}$ & 0.111 & 0.163 & 0.283 & 0.269 & 0.346 \\
\hline $\begin{array}{c}\text { Log likelihood } \\
(\mathrm{p} \text {-value })\end{array}$ & $\begin{array}{c}-782.78 \\
(0.000) \\
\end{array}$ & $\begin{array}{c}-707.23 \\
(0.000) \\
\end{array}$ & $\begin{array}{l}-668.12 \\
(0.000) \\
\end{array}$ & $\begin{array}{l}-567.78 \\
(0.000) \\
\end{array}$ & $\begin{array}{l}-467.67 \\
(0.000) \\
\end{array}$ \\
\hline \multicolumn{6}{|l|}{ Controls } \\
\hline Constant & $\begin{array}{c}-4.219 * * \\
(1.021) \\
\end{array}$ & $\begin{array}{c}-5.090 * * \\
(1.327) \\
\end{array}$ & $\begin{array}{c}-5.896 * * \\
(1.554)\end{array}$ & $\begin{array}{c}-6.458 * * \\
(0.998)\end{array}$ & $\begin{array}{c}-7.130 * * \\
(1.343) \\
\end{array}$ \\
\hline Electronics & $\begin{array}{l}0.803 * \\
(0.584)\end{array}$ & $\begin{array}{l}0.885^{*} \\
(0.601)\end{array}$ & $\begin{array}{l}0.998 * \\
(0.667)\end{array}$ & $\begin{array}{l}1.004 * \\
(0.381)\end{array}$ & $\begin{array}{l}1.058 * \\
(0.489)\end{array}$ \\
\hline Chemicals & $\begin{array}{c}0.727 \\
(0.432)\end{array}$ & $\begin{array}{c}0.733 \\
(0.419)\end{array}$ & $\begin{array}{c}0.808 \\
(0.501)\end{array}$ & $\begin{array}{c}0.721 \\
(0.321)\end{array}$ & $\begin{array}{c}0.694 \\
(0.289)\end{array}$ \\
\hline Process \& Precision Engineering & $\begin{array}{l}0.679^{\dagger} \\
(0.487) \\
\end{array}$ & $\begin{array}{l}0.692^{\dagger} \\
(0.490) \\
\end{array}$ & $\begin{array}{l}0.688^{\dagger} \\
(0.501) \\
\end{array}$ & $\begin{array}{l}0.703^{\dagger} \\
(0.456) \\
\end{array}$ & $\begin{array}{l}0.711^{\dagger} \\
(0.462)\end{array}$ \\
\hline Foreign & $\begin{array}{l}-0.422 \\
(0.338)\end{array}$ & $\begin{array}{l}-0.393 \\
(0.320)\end{array}$ & $\begin{array}{l}-0.406 \\
(0.318)\end{array}$ & $\begin{array}{l}-0.672 \\
(0.404)\end{array}$ & $\begin{array}{l}-0.689 \\
(0.421)\end{array}$ \\
\hline Firm Size & $\begin{array}{c}0.345 \\
(0.283) \\
\end{array}$ & $\begin{array}{c}0.354 \\
(0.299) \\
\end{array}$ & $\begin{array}{c}0.360 \\
(0.301) \\
\end{array}$ & $\begin{array}{c}0.402 \\
(0.299) \\
\end{array}$ & $\begin{array}{c}0.410 \\
(0.333) \\
\end{array}$ \\
\hline Government Linked Status & $\begin{array}{l}0.933 * \\
(0.698)\end{array}$ & $\begin{array}{l}0.959 * \\
(0.622)\end{array}$ & $\begin{array}{l}0.989 * \\
(0.631)\end{array}$ & $\begin{array}{l}1.338 * \\
(0.581)\end{array}$ & $\begin{array}{l}1.353 * \\
(0.605)\end{array}$ \\
\hline Sales Growth Rate & $\begin{array}{c}0.213^{\dagger} \\
(0.333)\end{array}$ & $\begin{array}{c}0.225^{\dagger} \\
(0.378)\end{array}$ & $\begin{array}{c}0.202^{\dagger} \\
(0.321)\end{array}$ & $\begin{array}{c}0.318^{\dagger} \\
(0.301)\end{array}$ & $\begin{array}{c}0.323^{\dagger} \\
(0.315)\end{array}$ \\
\hline Herfindahl Index & $\begin{array}{c}0.182 \\
(0.299)\end{array}$ & $\begin{array}{c}0.175 \\
(0.278)\end{array}$ & $\begin{array}{c}0.169 \\
(0.265)\end{array}$ & $\begin{array}{c}0.111 \\
(0.212)\end{array}$ & $\begin{array}{c}0.109 \\
(0.229)\end{array}$ \\
\hline \multicolumn{6}{|l|}{ Independent Variables } \\
\hline Innovation & & $\begin{array}{l}1.172 * \\
(0.612)\end{array}$ & & & \\
\hline Product Innovation Intensity & & & $\begin{array}{c}0.866^{*} \\
(0.548)\end{array}$ & & $\begin{array}{c}1.035^{*} \\
(0.599)\end{array}$ \\
\hline Process Innovation Intensity & & & $\begin{array}{c}-0.672 * \\
(0.303)\end{array}$ & & $\begin{array}{c}-0.906^{*} \\
(0.635)\end{array}$ \\
\hline
\end{tabular}

Note: ${ }^{\dagger} \mathrm{p}<0.10 ; * \mathrm{p}<0.05 ; * * \mathrm{p}<0.01$. All tests are two-tailed 


\section{TABLE IV}

Logistic Regression for Propensity of Individuals Leaving Their Organizations to Start Their Own Businesses (1-Yes; 0- No) $\mathrm{N}=371$

\begin{tabular}{|c|c|c|c|c|c|c|c|}
\hline & \multicolumn{2}{|c|}{ Model 1: Controls } & \multicolumn{2}{|c|}{$\begin{array}{l}\text { Model 2: Controls + } \\
\text { Innovation }\end{array}$} & \multicolumn{3}{|c|}{$\begin{array}{l}\text { Model 3: Controls + Product and Process } \\
\text { Innovation Intensities }\end{array}$} \\
\hline Nagelkerke R- Squared & \multicolumn{2}{|c|}{0.095} & \multicolumn{2}{|c|}{0.158} & \multicolumn{3}{|c|}{0.315} \\
\hline Chi Square (d.f.) & \multicolumn{2}{|c|}{$17.340(8)$} & \multicolumn{2}{|c|}{$20.941(9)$} & \multicolumn{3}{|c|}{$23.961(10)$} \\
\hline Probability & \multicolumn{2}{|c|}{0.019} & \multicolumn{2}{|c|}{0.007} & \multicolumn{3}{|c|}{0.005} \\
\hline & B & Sig & B & Sig & B & Sig & ODDS RATIO \\
\hline \multicolumn{8}{|l|}{ Controls } \\
\hline Constant & -3.080 & 0.000 & -3.045 & 0.000 & -3.419 & 0.000 & 0.005 \\
\hline Electronics & 1.322 & 0.045 & 1.132 & 0.047 & 1.466 & 0.037 & 1.504 \\
\hline Chemicals & 1.115 & 0.131 & 0.921 & 0.228 & 1.328 & 0.103 & 0.683 \\
\hline $\begin{array}{l}\text { Process \& Precision } \\
\text { Engineering }\end{array}$ & 1.126 & 0.047 & 1.004 & 0.063 & 1.323 & 0.044 & 1.523 \\
\hline Foreign & -0.433 & 0.249 & -0.448 & 0.160 & -0.355 & 0.238 & 0.530 \\
\hline Firm Size & 0.056 & 0.594 & -0.010 & 0.837 & 0.074 & 0.522 & 0.303 \\
\hline Government Linked Status & 1.713 & 0.009 & 1.284 & 0.020 & 1.722 & 0.006 & 1.566 \\
\hline Sales Growth Rate & 0.017 & 0.042 & 0.023 & 0.053 & 0.015 & 0.047 & 1.539 \\
\hline Herfindahl Index & -0.065 & 0.145 & -0.066 & 0.138 & -0.071 & 0.140 & 0.478 \\
\hline \multicolumn{8}{|l|}{ Independent Variables } \\
\hline Innovation & & & 0.823 & 0.026 & & & 3.843 \\
\hline Product Innovation Intensity & & & & & 0.128 & 0.013 & 2.790 \\
\hline Process Innovation Intensity & & & & & -0.085 & 0.046 & 2.124 \\
\hline
\end{tabular}

Note: ${ }^{\dagger} \mathrm{p}<0.10 ; * \mathrm{p}<0.05 ; * * \mathrm{p}<0.01$. All tests are two-tailed 


\section{APPENDIX I}

Measure Items and Response Format

Variables

Dependent variable

a) Propensity of start-up companies by ex-employees

Do you know of any start-up companies by ex-employees of

your firm in Singapore in the last 3 years that employ

similar technology as your firm?

b) Number of start-up companies by ex-employees

If you know of start-up companies by ex-employees of your firms in

Singapore in the last 3 years that employ similar technology as your firm,

please state how many start-ups?

Independent variables

a) Innovation

Over the last 3 years, has your enterprise introduced into

the market any product innovation?

Over the last 3 years, has your enterprise introduced into the

market any process innovation?

\section{b) Product innovation intensity}

Please indicate the approximate $\%$ of your total annual sales that consist Percentage

of new/improved products introduced over the last 3 years:

c) Process innovation intensity

Please indicate the approximate \% of your production volume using

new/improved processes introduced over the last 3 years:

\section{Control variables}

a) Industry dummies

b) Firm size

Total employment (full-time equivalent)

c) Foreign ownership

Wholly foreign-owned company

$30 \%$ or less locally owned

d) Government-linked firm

e) Sales growth rate

Average growth date of sales in the last 3 years: Percentage

f) Herfindahl index

Hindex $=$ Firm's sales/Total sales in sector

Percentage

Count data

Yes, No

Yes, No

Yes, No

Index
Yes, No

Measurements

Yes, No

Count data

Yes, No

Electronics, Chemicals, Process and Precision Engineering, Transportation Engineering 